\title{
Short communication: The effects of dry matter and length of storage on the composition and nutritive value of alfalfa silage
}

\author{
M. C. Santos and L. Kung Jr. ${ }^{1}$ \\ Department of Animal and Food Sciences, University of Delaware, Newark 19716
}

\begin{abstract}
During the ensiling of feeds, various processes result in chemical changes that can affect their ultimate nutritive value at feed out. The primary objective of this study was to evaluate the effect of prolonged ensiling times on potential changes in in vitro digestibility of neutral detergent fiber (NDF-D) of alfalfa ensiled at about $33 \%$ [low dry matter (DM), LDM] or $45 \%$ (high DM, HDM) whole-plant DM. Alfalfa from the same field (direct chopped or wilted) was chopped with a conventional forage harvester set for a theoretical length of cut of $0.95 \mathrm{~cm}$ and ensiled in mini silos for 45, 180, 270, and $360 \mathrm{~d}$. Fresh forages and silages were analyzed for nutrient content, fermentation end-products, and 30-h NDF-D. The $\mathrm{pH}$ of the fresh forages ranged from 6.1 to 6.2 and decreased to approximately 4.7 and 4.3 in HDM and LDM silages, respectively. Production of acids and alcohols were less in HDM compared with LDM as expected. Concentrations of soluble protein and $\mathrm{NH}_{3}-\mathrm{N}$ also increased with time of storage as expected but soluble protein was greater, whereas $\mathrm{NH}_{3}-\mathrm{N}$ was lower in HDM compared with LDM silage. The effect of length of storage and DM on hemicellulose and NDF concentrations were very small, whereas DM content at harvest tended to slightly increase the concentration of acid detergent fiber in HDM compared with LDM up to $270 \mathrm{~d}$ of storage. The NDF-D was greater in fresh forage compared with corresponding silages. However, time of storage between 45 and $360 \mathrm{~d}$ had no effect on the NDF-D of alfalfa silage, regardless of DM concentration at ensiling.
\end{abstract}

Key words: silage, fiber digestibility, alfalfa

\section{Short Communication}

Metabolic processes during the fermentation of forages have the potential to alter the original nutritive value of the standing crop. True protein content declines whereas soluble protein increases due to proteolytic processes (Winters et al., 2001). Especially

Received January 7, 2016.

Accepted March 15, 2016.

${ }^{1}$ Corresponding author: lksilage@udel.edu in corn silage, it is well known that these proteolytic processes are associated with degradation of prolamins, ultimately resulting in an increase in potential ruminal starch digestion (Hoffman et al., 2011). Changes in fibrous structural components in forages have also been reported during ensiling. For example, Yahaya et al. (2001) reported large losses in hemicellulose from alfalfa and orchardgrass after $56 \mathrm{~d}$ of ensiling. They also reported a decrease in hemicellulose digestion in alfalfa and orchardgrass silages but an increase in cellulose digestion for the former. We could not find any experiments that evaluated the effects of prolonged ensiling times on NDF-D of alfalfa. Thus, the primary objective of this study was to investigate the effect of a relatively prolonged length of storage (i.e., up to $360 \mathrm{~d}$ ) on the chemical composition and digestibility of NDF of alfalfa silage harvested at 2 different concentrations of DM.

On June 26, 2009, second-cut alfalfa (early bloom stage) from one field was harvested at the University of Delaware farm in Newark and immediately ensiled at a DM content of $33 \%$ (low DM, LDM) or forage was field-wilted and ensiled at a DM content of $45 \%$ (high DM, HDM). In both cases, forages were chopped with a conventional forage harvester set for a theoretical length of cut of $0.95 \mathrm{~cm}$, and ensiled (without additives) for 45, 180, 270, and $360 \mathrm{~d}$. About $500 \mathrm{~g}$ of chopped forage was packed in nylon-polyethylene standard barrier micro-layered pouches (3.5-mil thickness, $15.2 \times$ $30.5 \mathrm{~cm}$; Doug Care Equipment Inc., Springville, CA), evacuated, and heat sealed with a Best Vac vacuum machine (distributed by Doug Care Equipment Inc.). Bags had a layer of polyethylene mesh sealed into the entire length of the pouch, which assisted in the removal of air during the vacuum process. A total of 5 mini-silos were prepared for each DM and for each time of ensiling. Chopped samples of fresh forages from each DM served as replicate samples for d 0. Silos were stored between 22 and $23^{\circ} \mathrm{C}$ until opening. Silages were dried in a forced draft oven at $60^{\circ} \mathrm{C}$ for $48 \mathrm{~h}$. The NDF content of samples was determined by the method of Van Soest et al. (1991) with a heat-stable amylase and sulfite. In vitro 30-h digestibility of NDF (2-mm screen, Udy Cyclone mill, Udy Corp., Fort Collins, CO) was 
determined according to the methodology described by Goering and Van Soest (1970) using flasks as incubation vessels. All other analyses for nutrient and chemical content were as described by Der Bedrosian et al. (2012).

The data were analyzed as a $2 \times 5$ factorial arrangement of treatments with factors including $2 \mathrm{DM}$ concentrations (LDM and HDM) and 5 lengths of storage $(0,45,180,270$, and $360 \mathrm{~d})$. The main effects evaluated were DM concentration, length of storage, and their interaction. Data were analyzed with the ANOVA method of the least squares fit model procedure of JMP (SAS Institute Inc., Cary, NC) and differences were reported as significant when $P \leq 0.05$.

The statistical analysis of the data set is in Table 1 , and changes of components during storage are in Figures 1 to 4 . Specifically, there was an interaction $(P$ $<0.01$ ) between DM content at ensiling and length of storage for DM content because it remained relatively constant for low DM silage, but increased for HDM silage (Figure 1). There was also an interaction $(P<0.01)$ between DM content at ensiling and length of storage for $\mathrm{pH}$ primarily because $\mathrm{pH}$ was similar in fresh forage, but declined more in LDM than HDM silage (Figure 1). Differences in most fermentation end-products (Figure 2) affected by DM content and the changes in them due to length of ensiling were as expected. For example, $\mathrm{pH}$ was greater, and concentrations of lactic and acetic acids, ethanol, and 1,2-propanediol were reduced in HDM compared with LDM alfalfa silage. These observations were most likely because there is less metabolic water available in high DM silages to support microbial growth (Muck, 1990; Whiter and Kung, 2001) and overall fermentation. The pronounced appearance of 1,2-propanediol at $180 \mathrm{~d}$ for LDM indicated that certain processes in silage were still occurring even after several months of storage. This compound is a product of metabolism of Lactobacillus buchneri, and Kleinschmit and Kung (2006) and Schmidt et al. (2009) reported that Lactobacillus buchneri remains active for prolonged periods in silage, even at low $\mathrm{pH}$.

Changes in the nitrogenous components of silages are shown in Figure 3. The concentration of CP increased with length of storage, perhaps because of DM losses occurring during fermentation, but was less in HDM compared with LDM silage, probably due to some leaf loss during harvest of the HDM material. The concentrations of soluble protein and $\mathrm{NH}_{3}-\mathrm{N}$ increased as expected with length of storage, and most of the increase occurred between 0 and $45 \mathrm{~d}$. Unlike fermentation acids and alcohols, the concentration of soluble protein was not inversely related to DM concentration, which agrees with the findings of Muck (1990), who reported that the total amount of proteolysis for silages with
A)

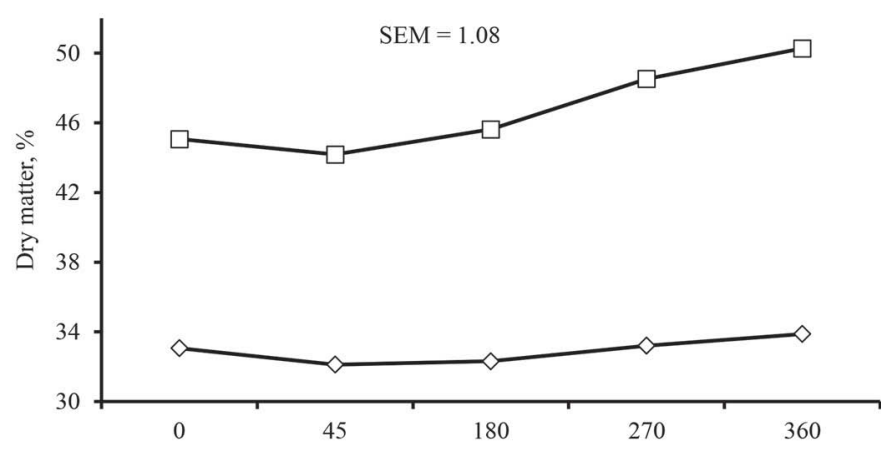

B)

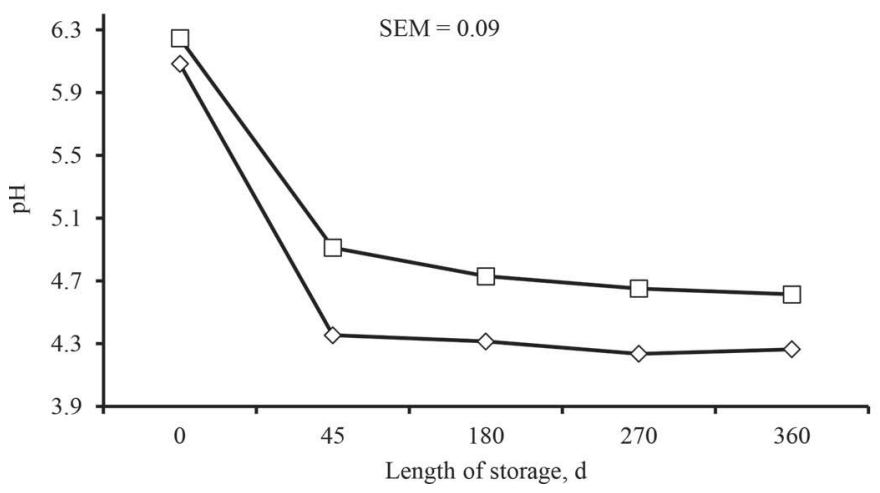

Figure 1. Dry matter percentage (A, \%) and $\mathrm{pH}$ (B) of forages; $\diamond$ $=$ alfalfa ensiled at low DM content; $\square=$ alfalfa ensiled at high DM content.

DM $<50 \%$ was not closely correlated with DM content. Although soluble protein was greater in HDM $(68 \%$ of $\mathrm{CP}$ ) compared LDM ( $67 \%$ of $\mathrm{CP})$, this difference was small and not biologically important. Although the concentration of $\mathrm{NH}_{3}-\mathrm{N}$ was not affected $(P=0.67)$

Table 1. Statistical analysis ( $P$-values) of the influence of DM content at harvest (DM) and length of storage (LS) on the nutritive value (DM basis unless stated otherwise) of alfalfa silage

\begin{tabular}{lrrr}
\hline Item & DM & LS & DM $\times$ LS \\
\hline DM, \% & $<0.01$ & $<0.01$ & $<0.01$ \\
pH & $<0.01$ & $<0.01$ & $<0.01$ \\
Lactic acid, \% & $<0.01$ & $<0.01$ & 0.35 \\
Acetic acid, \% & $<0.01$ & $<0.01$ & $<0.01$ \\
Ethanol, \% & 0.01 & $<0.01$ & 0.01 \\
1,2-propanediol, \% & $<0.01$ & $<0.01$ & $<0.01$ \\
CP, \% & $<0.01$ & $<0.01$ & 0.61 \\
SP, \% of CP & 0.02 & $<0.01$ & 0.07 \\
Ammonia-N, \% & $<0.01$ & $<0.01$ & 0.67 \\
ADF, \% & 0.06 & 0.50 & 0.22 \\
Hemicellulose, \% & 0.14 & 0.37 & 0.06 \\
NDF, \% & 0.51 & 0.03 & 0.03 \\
NDF-D, $\%$ of NDF & $<0.01$ & $<0.01$ & 0.03 \\
\hline
\end{tabular}

${ }^{1}$ Soluble protein.

${ }^{2}$ In vitro NDF-digestibility, $30 \mathrm{~h}$. 

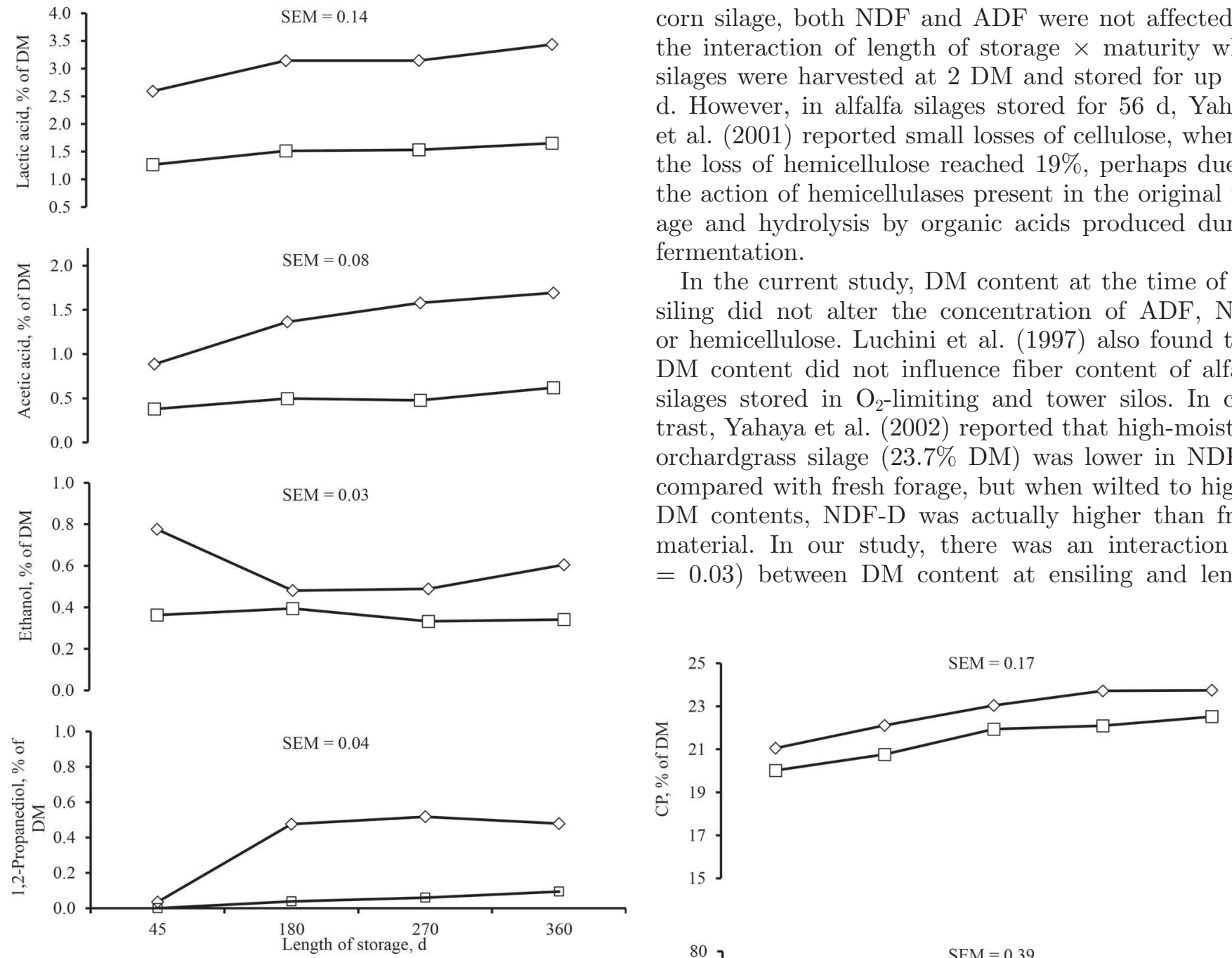

Figure 2. The concentrations (\% DM basis) of lactic acid, acetic acid, ethanol, and 1,2-propanediol in silages; $\diamond=$ alfalfa ensiled at low DM content; $\square=$ alfalfa ensiled at high DM content.

by the interaction between DM content at ensiling and length of storage, $\mathrm{NH}_{3}-\mathrm{N}$ was lower $(P<0.01)$ in $\mathrm{HDM}$ than LDM, probably because it is primarily an endproduct of microbial metabolism, which is reduced in high DM silages with low water activity.

The concentrations of ADF, NDF, hemicellulose, and NDF-D are given in Figure 4. The DM concentration at ensiling did not affect $(P \geq 0.06)$ the concentrations of ADF, NDF, or hemicellulose. Length of storage also did not affect $(P \geq 0.37)$ the concentrations of $\mathrm{ADF}$ and hemicellulose. Although statistically significant, the interaction of length of storage $\times \mathrm{DM}$ on NDF and the effect of length of storage on NDF were very small. In corn silages, Sanderson (1993) reported that NDF content was not altered during $186 \mathrm{~d}$ of fermentation. Similarly, Der Bedrosian et al. (2012) reported that, in

corn silage, both NDF and ADF were not affected by the interaction of length of storage $\times$ maturity when silages were harvested at $2 \mathrm{DM}$ and stored for up 360 d. However, in alfalfa silages stored for $56 \mathrm{~d}$, Yahaya et al. (2001) reported small losses of cellulose, whereas the loss of hemicellulose reached $19 \%$, perhaps due to the action of hemicellulases present in the original forage and hydrolysis by organic acids produced during fermentation.

In the current study, DM content at the time of ensiling did not alter the concentration of ADF, NDF or hemicellulose. Luchini et al. (1997) also found that DM content did not influence fiber content of alfalfa silages stored in $\mathrm{O}_{2}$-limiting and tower silos. In contrast, Yahaya et al. (2002) reported that high-moisture orchardgrass silage $(23.7 \% \mathrm{DM})$ was lower in NDF-D compared with fresh forage, but when wilted to higher DM contents, NDF-D was actually higher than fresh material. In our study, there was an interaction $(P$ $=0.03)$ between DM content at ensiling and length
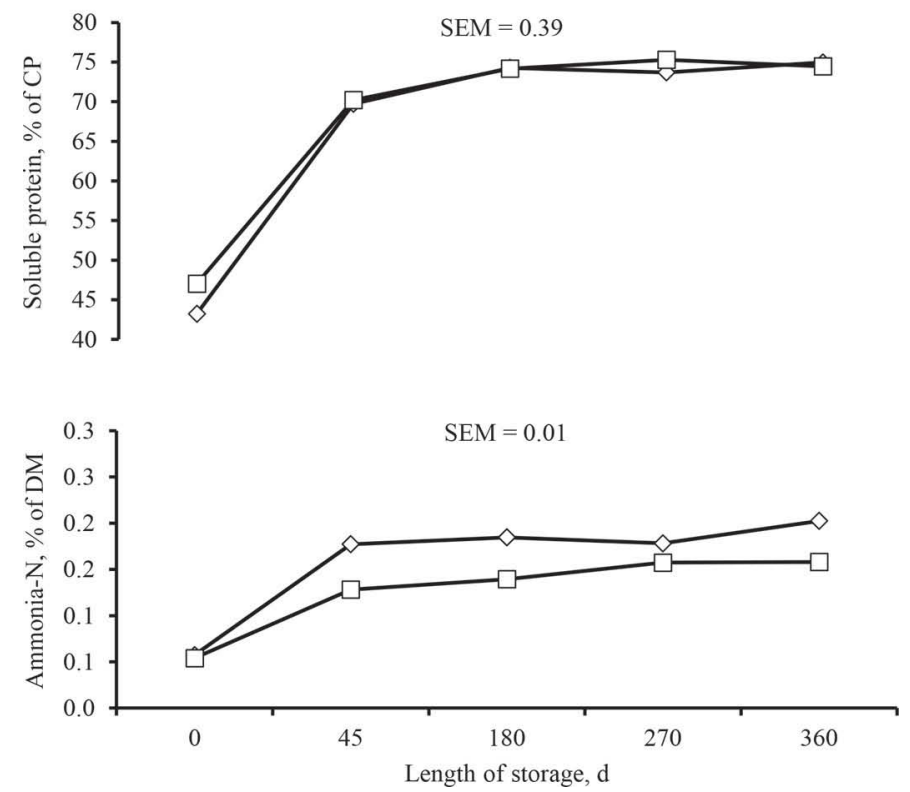

Figure 3. The concentrations of CP (\% of DM), soluble protein (\% of $\mathrm{CP}$ ), and ammonia-N (\% of DM) of forages; $\diamond=$ alfalfa ensiled at low DM content; $\square=$ alfalfa ensiled at high DM content. 



Figure 4. The concentrations of ADF ( $\%$ of DM), hemicellulose (\% of DM), NDF (\% of DM), and NDF digestibility (NDF-D; \% of NDF) of forages; $\diamond=$ alfalfa ensiled at low DM content; $\square=$ alfalfa ensiled at high DM content.

of storage for NDF-D primarily because NDF-D was greater and similar in fresh forages but was slightly lower from d 45 onward for HDM compared with LDM silage, with the former being slightly lower. A slight decrease in NDF-D between fresh and ensiled samples has been reported by others (Sanderson, 1993; Der Bedrosian et al., 2012) but importantly, in our study, NDF-D was not different within a concentration of DM between 45 and $360 \mathrm{~d}$ of storage. These findings agree with those of Der Bedrosian et al. (2012) with corn silage, who reported little change in NDF-D between 45 and $360 \mathrm{~d}$ of storage. The results of the current study show that potential ruminal NDF digestibility is not affected by prolonged storage of alfalfa silage through 1 yr of storage, regardless of the DM content at harvest.

\section{ACKNOWLEDGMENTS}

The authors thank the farm staff of the University of Delaware farm for assistance with forage harvesting and Michelle Windle for assistance in preparing the laboratory silos.

\section{REFERENCES}

Der Bedrosian, M. C., K. E. Nestor Jr., and L. Kung Jr. 2012. The effects of hybrid, maturity, and length of storage on the composition and nutritive value of corn silage. J. Dairy Sci. 95:5115-5126.

Goering, H. K., and P. J. Van Soest. 1970. Forage fiber analyses (apparatus, reagents, procedures, and some applications). Agric. Handbook 379. Agricultural Research Service, USDA, Washington, DC.

Hoffman, P. C., N. M. Esser, R. D. Shaver, W. Coblentz, M. P. Scott, A. L. Bodnar, R. Schmidt, and R. Charley. 2011. Influence of ensiling time and inoculation on alteration o the starch-protein matrix in high-moisture corn. J. Dairy Sci. 94:2465-2474.

Kleinschmit, D. H., and L. Kung Jr.. 2006. The effects of Lactobacillus buchneri 40788 and Pediococcus pentosaceus R1094 on the fermentation of corn silage during various stages of ensiling. J. Dairy Sci. 89:3999-4004.

Luchini, N. D., G. A. Broderick, R. E. Muck, N. F. Makoni, and R. L. Vetter. 1997. Effect of storage system and dry matter content on the composition of alfalfa silage. J. Dairy Sci. 80:1827-1832.

Muck, R. E. 1990. Dry matter level effects on alfalfa silage quality. II. Fermentation products and starch hydrolysis. Trans. ASAE 33:373-381.

Sanderson, M. A. 1993. Aerobic stability and in vitro fiber digestibility of microbially inoculated corn and sorghum silage. J. Anim. Sci. 71:505-514.

Schmidt, R. J., W. Hu, J. A. Mills, and L. Kung Jr.. 2009. The development of lactic acid bacteria and Lactobacillus buchneri and their effects on the fermentation of alfalfa silage. J. Dairy Sci. 92:5005-5010.

Van Soest, P. J., J. B. Robertson, and B. A. Lewis. 1991. Methods for dietary fiber, neutral detergent fiber, and nonstarch polysaccharides in relation to animal nutrition. J. Dairy Sci. 74:3583-3597.

Whiter, A. G., and L. Kung Jr.. 2001. The effect of a dry or liquid application of Lactobacillus plantarum MTD1 on the fermentation of alfalfa silage. J. Dairy Sci. 84:2195-2202.

Winters, A. L., R. Fychan, and R. Jones. 2001. Effect of formic acid and a bacterial inoculant on the amino acid composition of grass silage and on animal performance. Grass Forage Sci. 56:181-192.

Yahaya, M. S., M. Kawai, J. Takahashi, and S. Matsuoka. 2002. The effect of different moisture contents at ensiling on silo degradation and digestibility of structural carbohydrates of orchardgrass. Anim. Feed Sci. Technol. 101:127-133.

Yahaya, M. S., A. Kimura, J. Harai, H. V. Nguyen, M. Kawai, J. Takahashi, and S. Matsuoka. 2001. Effect of length of ensiling on silo degradation and digestibility of structural carbohydrates of lucerne and orchardgrass. Anim. Feed Sci. Technol. 92:141-148. 